appear at, or very near, the beginning of the lymphoid cell population of this organ. It has recently been demonstrated that certain antigens may elicit an immune response even in utero ${ }^{18,18}$. This capacity to respond very early in life may be related to the existence of a low background level of RFC in utero. It is not yet clear whether this specific cyto-adherence property appears with or without previous contact with some cross-reacting antigen.

I thank Mrs Miriam Schlezinger for skilful technical assistance.

\section{R. LASKOV*}

Department of Experimental Medicine and

Cancer Research,

The Hebrew University-Hadassah Medical School, Jerusalem, Israel.

Received January 29; revised June 17, 1968.

- Present address: Department of Cell Biology, Albert Einstein College of Medicine, Yeshiva University, Bronx, New York.

' Jerne, N. K., and Nordin, A. A., Science, 140, 405 (1963).

${ }^{2}$ Ingraham, J. S., and Bussard, A., J. Exp. Med., 119, 667 (1964).

${ }^{3}$ Nota, N. R., Liacopoulos-Briot, M., Stiffel, C., and Biozzi, G., CR Acad. Sci., 258, 1277 (1964).

${ }^{4}$ Zaalberg, O. B., Nature, 202, 1231 (1964).

'Cunningham, A. J., Nature, 20\%, 1106 (1965).

${ }^{6}$ Zaalberg, O. B., Van der Meul, V. A., and Van Twisk, J. M., Nature, 210, $544(1966)$.

'Hege, J. S., and Cole, J. J., J. Immunol., 99, 61 (1967).

${ }^{3}$ Biozzi, G., Stiffel, C., Mouton, D., Liacopoulos-Briot, M., Decreusefond, C., and Bouthiller, $\dot{Y}_{.,}$Ann. Inst. Pasteur, 110, 7 (1966).

${ }^{2}$ Boyden, S. V., and Sorkin, E., Immunology, 8, $272(1960)$ ${ }^{10}$ Baker, P. J., Bernstein, M., Pasanen, V., and Landy, M., J. Immunol., 97,

"Dent, P. B., and Good, R. A., Nature, 207, 491 (1965).

${ }^{12}$ Boyden, S. V., Immunology, "7, 474 (1964).

is Storb, U., and Weiser, R. S., J. Reticuloendothelial Soc., 4, 51 (1967).

14 Friedman, H., Experientia, 20, 564 (1964).

${ }^{16}$ Nakano, M., and Braun, W., Science, 151, 338 (1966).

${ }^{16}$ Schlezinger, M., J. Immunol., 93, 255 (1964).

${ }^{17}$ Prindull, G., Zeit. Anat. und Eintwickl., 125, 255 (1966).

${ }^{2}$ Silverstein, A. M., Uhr, J. W., Kraner, K. L., and Lukes, R. J., J. Exp. Med., 117,799 (1963)

${ }^{19}$ I, a Via, M. F., Rowlands, D. T., and Black, M., Science, 140, 1219 (1963).

\section{Effect of Lymphocyte Stimulants on Specific Antibody Synthesis in vitro}

SinCE Nowell's original description of phytohaemagglutinin (PHA)-induced lymphocyte transformation ${ }^{1}$, there has been considerable controversy as to whether responses to this substance involve immunoglobulin and specific antibody synthesis. Several workers ${ }^{2-5}$, using a variety of techniques, claim to have demonstrated immunoglobulin synthesis by PHA-stimulated human peripheral blood lymphocyte cultures, but others have been unable to confirm these findings ${ }^{6-8}$. Recent studies with the pokeweed mitogen (PWM) suggest that responses to this stimulant differ morphologically from those to PHA (ref. 10) and that a sub-population of cells responding to PWM may synthesize immunoglobulin ${ }^{9,11}$.

Forbes $^{12}$ has claimed that PHA stimulates anti-thyroglobulin synthesis in cultures of lymphocytes from Hashimoto patients. Using more precise controls, however, this finding could not be repeated ${ }^{9}$. Induction of specific antibody synthesis by peripheral blood Iymphocyte cultures might be a variable response dependent on the presence of sufficient numbers of suitably presensitized cells in the circulation at the time of the experiment ${ }^{13}$. From this point of view, cultures of lymph node or spleen tissue might provide a richer source of sensitized cells and make possible investigation of the role of specific antigen and lymphocyte mitogens such as PHA and PWM in stimulating immunological responses.

A few reports have been published of attempts to elicit or modify immunological responses in vitro with PHA using presensitized lymph node or spleen tissue. Tao ${ }^{14}$, using lymph node fragments from presensitized rabbits, reported that PHA stimulates antibody production to bovine gonadotrophin in three out of five rabbits and to bovine serum albumin in one of two rabbits. Two to eight days after PHA stimulation, responding cultures contained four times the antibody of unstimulated cultures. Svehag ${ }^{15}$ reported that PHA did not enhance the effect of poliovirus antigen in eliciting a secondary response in vitro of presensitized rabbit spleen and lymph node cell suspensions grown on embryonic monolayers. The effect of PHA alone on presensitized cells was not reported. Using the haemolytic plaque technique and ${ }^{14} \mathrm{C}$-thymidine uptake, Harris and Littleton ${ }^{18}$ showed that PHA did not by itself stimulate a secondary response to sheep erythrocytes in sensitized rabbit spleen cell suspensions in vitro; neither did it enhance the effect of antigen. Furthermore, the additive effects of PHA and antigen on DNA synthesis strongly suggested that different populations of cells were being stimulated by the two stimuli. The conclusions of these authors, however, are based solely on the detection of direct or $19 \mathrm{~S}$ haemolytic antibody forming cells, and no attempt was made to detect "indirect" or $7 S$ plaque forming cells which predominate in secondary responses ${ }^{17}$. Furthermore, in their culture system antigen itself did not induce a particularly striking response compared with that reported by Richardson and Dutton ${ }^{18}$ using an essentially similar system. A few studies in vivo suggest that although PHA may influence antibody production it is incapable of inducing an anamnestic response when injected into presensitized animals ${ }^{17,18,20}$.

The experiments reported in this communication concern attempts to detect haemolytic antibody formation in vitro by unsensitized and presensitized rabbit spleen cell suspensions treated with either the immunizing antigen (sheep erythrocytes) or the phytomitogens, PHA and PWM.

Rabbits were irnmunized against sheep red blood cells (SRBC) by intravenous injection as described later. Rabbit spleens were removed aseptically and cut into several sections, which were then teased to remove all cells, leaving a colourless splenic capsule. The cell suspension was spun at low speed to remove large cell aggregates and the remaining suspension was washed twice in medium 199. Cells were cultured at a concentration of $0.8-1.0 \times 10^{7} / \mathrm{ml}$. in 20 per cent inactivated homologous serum (absorbed with SRBC) in 199 and gassed with 5 per cent $\mathrm{CO}_{2} /$ air. After 3 days a further $0.5 \mathrm{ml}$. of fresh complete medium was added to each culture.

PHA (Burroughs Wellcome) and PWM, prepared by the method of Borjeson et al. ${ }^{21}$, were added at predetermined optimal doses for transformation and DNA synthesis of $0.015 \mathrm{ml}$. and $75 \mu \mathrm{g} / \mathrm{ml}$. culture medium respectively. Washed sterile SRBC were added at a concentration of $5-7 \times 10^{6} / \mathrm{ml}$.

$2-{ }^{14} \mathrm{C}$-thymidine uptake was quantitated using the method of Ling and $\mathrm{Holt}^{22}$. Thymidine was added $16 \mathrm{~h}$ before the cells were collected.

Antibody synthesis was investigated by localized haemolysis in gel $^{23}$, antibody producing cells being identified as plaque forming cells (PFC). The original technique detects only $19 S$ antibody producing cells, that is, direct PFCs, and has been modified for experiments with mice using anti-mouse immunoglobulin in sera to detect $7 S$ antibody producing cells, that is, indirect or enhanced PFC (refs. 24 and 25). A similar technique of enhancement of 7S PFC has been used in the present experiments with rabbit spleen cells using a goat anti-rabbit $7 S$ serum. Antiserum was added to individual plates after direct PFC had been developed so as to avoid any inhibition of plaque formation.

Fig. 1 shows the effect of dilutions of anti-rabbit $7 S$ serum on the counts of PFCs in a spleen cell suspension prepared from a hyperimmunized rabbit (serum haemo- 
lytic titre $1: 640$ ). Actual numbers of indirect $\mathrm{PFC}$ have been obtained in each ease by subtracting direct PFC from total PFC on plates with antiserum. Normal in. activated goat serum was used as a control. As indicated, this antiserum increased the number of PFC for a considerable range of dilutions. The optimal dilution appeared to be $1: 25$ and this was used in subsequent experiments.

The result of stimulating spleen cells from an unsensitized rabbit with SRBC, PHA and PWM is shown in Fig. 2. Both PHA and PWM induced considerable lymphocyte transformation $(40-60$ per cent by day 3 ) and stimulated the uptake of $2{ }^{14} \mathrm{C}$-thymidine as shown. DNA synthesis in SRBC-stimulated cultures was only marginally greater than that of untreated cultures.

Background direct $\mathrm{PFC}$ on day 0 were $25 /$ culture ( $10^{7}$ cells). No indirect PFC were detected. The numbers of direct PFC did not increase above the background level in PHA or PWM stimulated cultures although on day 5 they were present in greater numbers than in untreated cultures.

SRBC-treated cultures showed evidence of a primary response to antigen with direct $\mathrm{PFC}$ increasing forty times above background on day 5 . No indirect or $7 \mathrm{~S}$ PFC were detected in any cultures.

The results of stimulating cells from a rabbit given a single injection of SRBC 5 weeks previously are shown in Fig. 3. The uptake of $2{ }^{14} \mathrm{C}$-thymidine stimulated by PHA and PWM-treated cultures was similar to that observed in the previous experiment. In contrast to the latter, however, SRBC induced a considerable uptake of thymidine above that observed in untreated cultures.

The background direct $\mathrm{PFC}$ on day 0 were 55/culture $\left(10^{7}\right.$ cells $)$ SRBC appeared to induce a direct PFC response similar in extent to that previously reported by Richardson and Dutton ${ }^{18}$ using a similar in vitro system. No attempt was made to quantitate indirect $\mathrm{PFC}$ in this experiment.

PHA and pokeweed induced no definite direct PFC response although the numbers of PFC in PHA cultures were greater than in untreated cultures. All the PFC on plates derived from PHA cultures were examined by high power phase contrast microscopy and in contrast to SRBCstimulated cultures more than 90 per cent of these plaques contained a central aggregate of six to fifteen large lymphoid cells. SRBC-induced plaques invariably contained a single central cell.

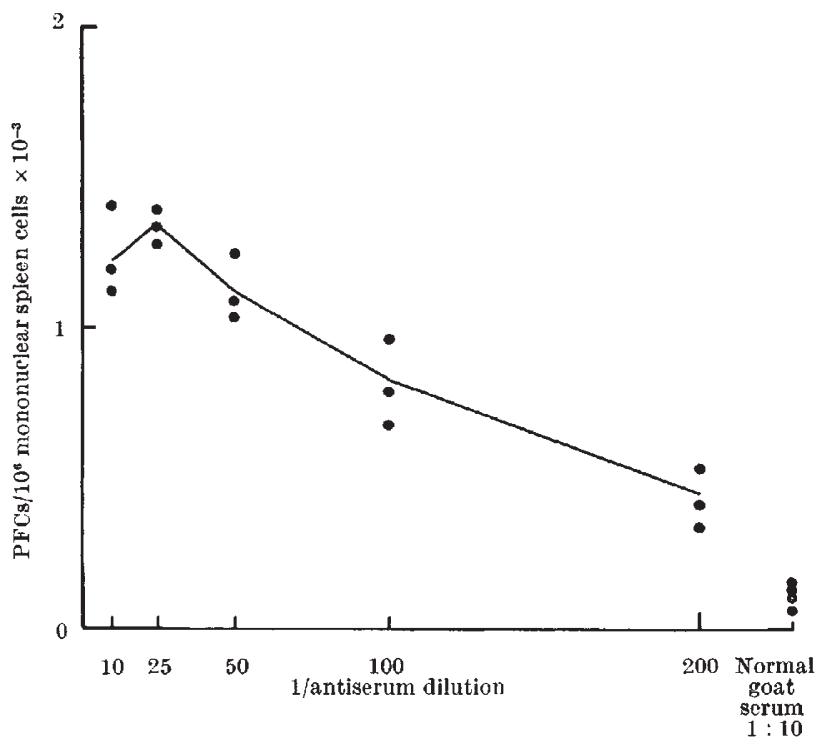

Fig. 1. Enhancement of numbers of plaque-forming cells by a goat anti-rabbit $7 S$ serum. Spleen cells were collected from a hyperimmune rabbit.

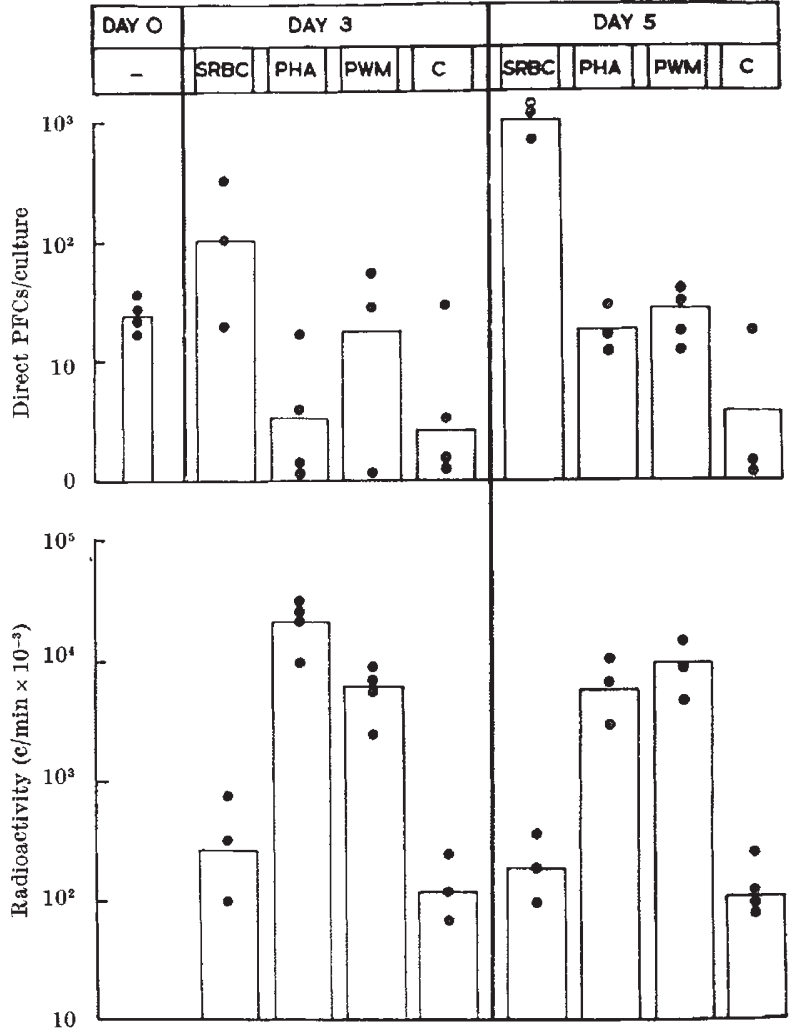

Fig. 2. Effect of sheep erythrocytes, phytohaemagglutinin and pokeweed mitogen on unsensitized rabbit spleen cells in vitro. Measurcment of direct plaque-forming cells and DNA synthesis (by ${ }^{14} \mathrm{C}$-thymidine uptake). The seale is logarithmic. C, Control, no stim

In a further experiment the formation of both direct and indirect plaques was determined and the effect of non-specific mitogens in combination with the antigen studied. Spleen cells were prepared from a rabbit 21 days after a second injection of SRBC. Serum haemolytic titre on day 0 was $1: 320$. The DNA response of cultures stimulated by SRBC, PHA and PWM was similar to the previous experiment; counts in untreated cultures were, however, considerably higher than previously obtained Fig. $4 a)$. Simultaneous addition of PHA or PWM to SRBC-treated cultures increased thymidine uptake above that observed in cultures treated with one stimulant alone. Although there was considerable variation between individual cultures of one group, the mean counts obtained in cultures with both SRBC and PHA or PWM suggested that the two types of mitogenic stimuli had an additive effect on the lymphocyte population, as far as stimulation of DNA synthesis was concerned.

Both direct and indirect PFC were present in considerable numbers on day 0 , reflecting the current, albeit declining, response of the rabbit on the day of the experiment (Fig. 4b).

SRBC alone induced a very considerable response in terms of both direct and indirect PFC (Fig. 4b). Because of a plating error indirect $\mathrm{PFC}$ were too numerous to count on day 3 but were more than $3,000 /$ culture $\left(8 \times 10^{6}\right.$ cells/day 0 ); by day 5 numbers of indirect $\mathrm{PFC}$ had risen to $350,000 /$ culture. Cultures treated simultaneously with SRBC and PHA or PWM showed no increase in either direct or indirect $\mathrm{PFC}$ above that observed in cultures treated with SRBC alone; in fact, a slight reduction of numbers was evident in cultures treated with SRBC plus PHA. PHA and PWM individually induced no response above background (day 0 ) although by day 5 numbers of indirect PFC were slightly greater than in untreated cultures. 


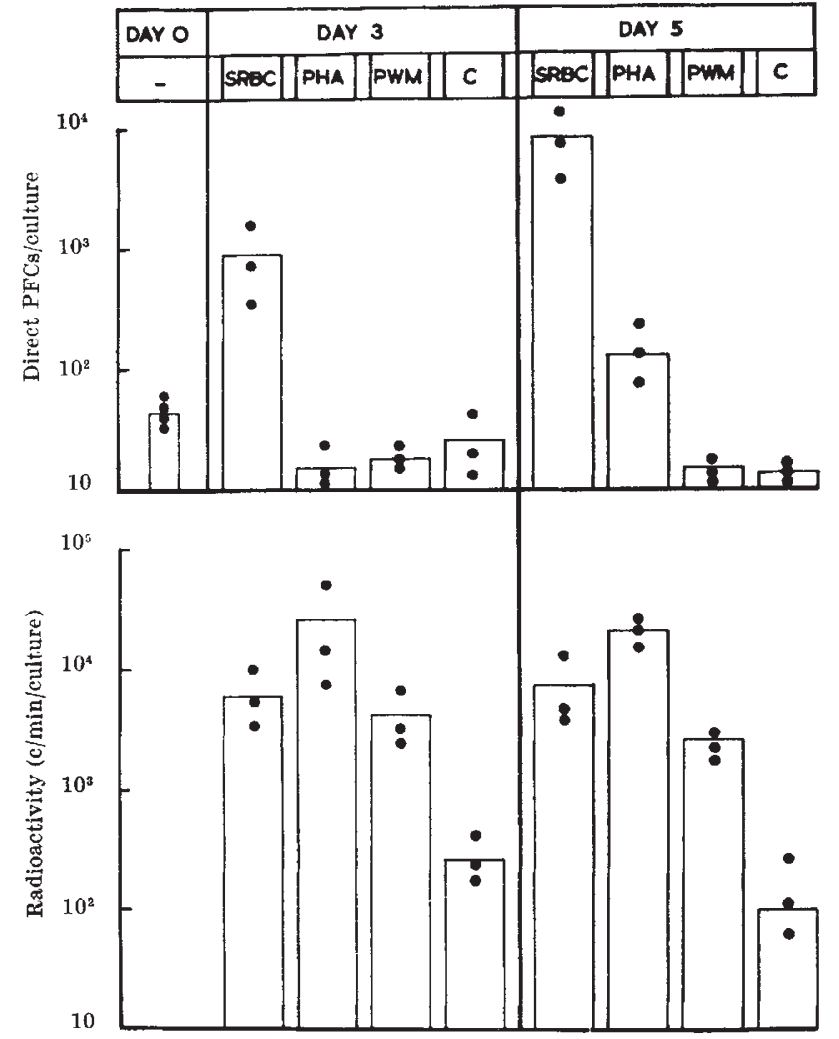

Fig. 3. Effect of sheep erythrocytes, phytohaemagglutinin and pokeof direct plaque-forming cells and DNA synthesis (by ${ }^{14} \mathrm{C}$-thymidine uptake).

These experiments with rabbit spleen cell suspensions provided firm evidence that, at least for this type of immunity, PHA and PWM have no capacity to replace the function of specific antigen in stimulating an anamnestic response. The method of detecting $7 S^{S}$ antibody, that is, indirect PFC, introduced originally for experiments with mice, works equally well in the rabbit system. Although no conclusive evidence has been presented to establish that indirect PFC were in fact $7 S$ antibody producing cells, this is the most likely interpretation of their nature in view of the specificity of the antibody used for their detection and the very large numbers of indirect PFC observed in the secondary response in vitro evoked in these experiments (compare ref. 24).

These experiments have also shown that using cell sus. pension culture excellent $19 S$ and $7 S$ antibody responses can be obtained, quite comparable with in vivo responses. It would also seem that at least a small primary response can be induced in vitro using this system as previously reported for mouse spleen cell suspensions cultured in more special conditions ${ }^{26}$.

Apart, from an extremely marginal response of ill-defined plaques observed with PHA stimulated cells in one experiment, there is no evidence to suggest that PHA or PWM is capable of stimulating a secondary response of haemolytic antibody-producing cells. Neither did PHA nor PWM enhance the stimulating effect of specific antigen on the development of PFC. These non-specific mitogens, however, did stimulate a very considerable blast cell response involving approximately 40-60 per cent of the lymphoid cells. The lack of significant effect on PFC numbers when these mitogens were combined with SRBC and the additive effect of these combinations on thymidine uptake strongly suggest that the lymphocytes responding to non-specific mitogens are distinct from those cells primed to respond to a specific antigen such as sheep erythrocytes.
Recent experiments on birds (unpublished work of M. F. Greaves, E. Rose and I. M. Roitt) and mammals ${ }^{27,28}$ have shown that the response to PHA is dependent on
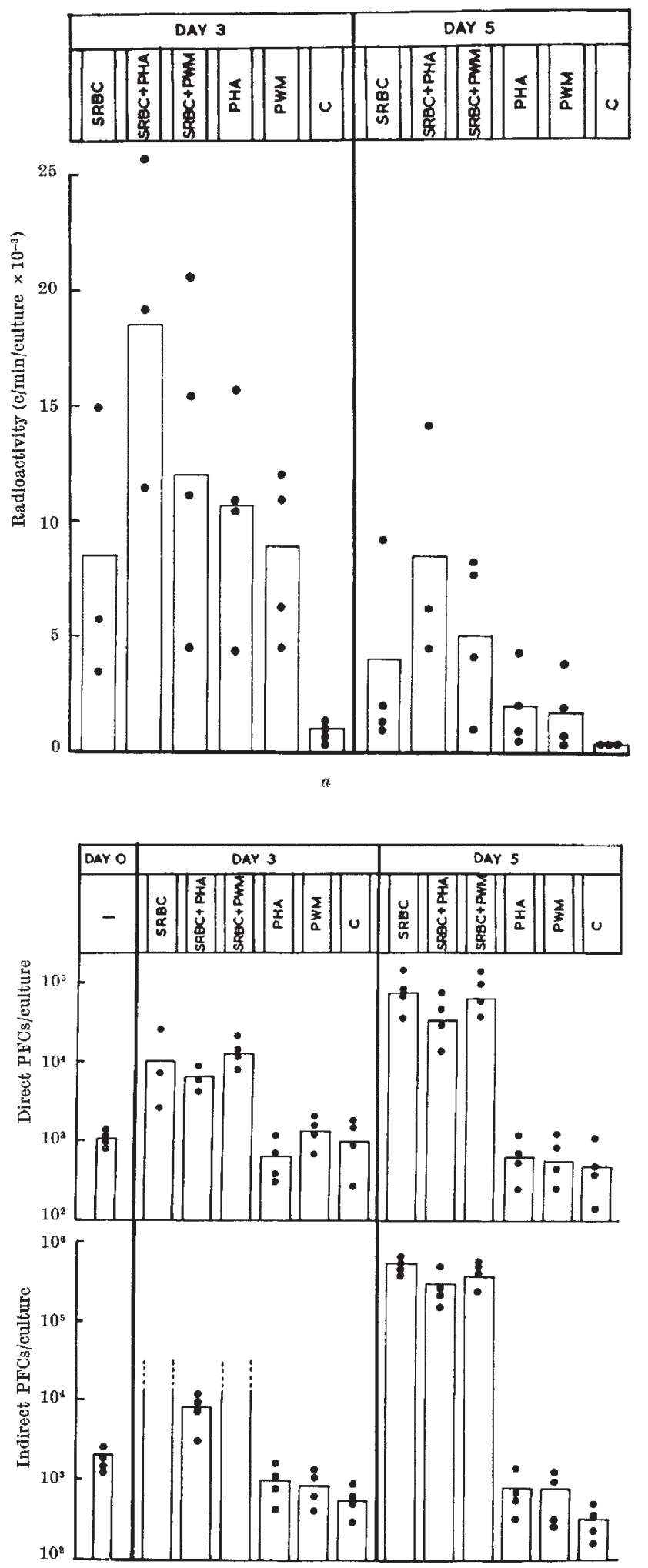

Fig. 4. $a$, Effect of sheep erythrocytes, phytohaemagglutinin and pokeweed mitogen on presensitized rabbit spleen cells in vitro. Spleen cells were collected from a hyperimmunized rabbit. Measurement of DNA

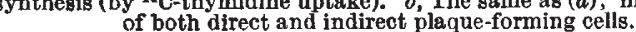


the thymus. Furthermore, most of these cells may be actually derived from the thymus ${ }^{29}$. It is interesting that cells derived from the thymus have been shown to respond mitotically to antigen, but appear not to produce antibody ${ }^{30}$. Possibly these cells are more directly involved in the expression of "cell-mediated" immune responses and the recent demonstration of immunoglobulin molecules on the cell surface ${ }^{\theta}$ of cells stimulated by PHA suggests a biochemical basis for the specificity of these reactions.

We thank Professor I. M. Roitt for his criticism of the manuscript. One of us (M. F. G.) is in receipt of a grant from the Medical Research Council. H-D. F. holds a fellowship of the Max Kade Foundation, New York.

\section{F. Greaves} H-D. FLAD*

Department of Immunology,

Middlesex Hospital Medical School, London W1.

Received June 14, 1968.

* Present address: Universität Ulm, Zentrum für Innere Medizin, Steinhövelstrasse 9, $79 \mathrm{Ulm} /$ Donau, West Germany.

${ }^{1}$ Nowell, P. C., Cancer Res., 20, 462 (1960).

${ }^{2}$ Hirschhorn, K., Bach, F', Kolodny, R. L., Firschein, I. L., and Hashem, N., Science, 142, 1185 (1963).

${ }^{3}$ Elves, M. W., Roath, S., Taylor, G., and Israels, M. C. G., Lancet, i, 1292 (1963).

4 Turner, K. J., and Forges, I. J., J. Immunol., 96, 926 (1966).

${ }^{5}$ Ripps, C. S., and Hirschhorn, K., Clin. Exp. Immunol., 2, 377 (1967).

${ }^{6}$ Sell, S., Rowe, D. S., and Gell, P. G. H., J. Exp. Med., 122, 823 (1965)

${ }^{7}$ Epstein, L. B., Fed. Proc., 25, 439 (1966).

${ }^{8}$ Greaves, M. F., in Proc. Symp. The Biological Effects of Phytohaemagylutinin, 53 (edit. by Elves, M. W., Oswestry, 1966).

${ }^{9}$ Greaves, M. F., and Roitt, I. M., Clin. Exp. Immunol., 3, 393 (1968).

so Douglas, J. D., Hoffman, P. F., Borjeson, J., and Chessin, J. N., J Immunoi., 98, 17 (1967).

${ }^{11}$ Greaves, M. F., and Roitt, I. M., Lancet, ii, 419 (1967).

${ }^{12}$ Forbes, I. J., Lancet, i, 198 (1965).

${ }^{13}$ Hullinger, L., and Sorkin, E., Nature, 198, 299 (1963).

${ }_{14}$ Tao, T-W., Science, 146, 247 (1964).

is Svehag, S. E., Archiv. fuer die gesamte Virusforschung, 15, 261 (1965).

${ }^{18}$ Harris, G., and Littleton, R. J., J. Exp. Med., 124, 621 (1966).

${ }^{17}$ Greaves, M. F., thesis, Univ. London (1968).

${ }^{18}$ Richardson, M., and Dutton, R. W., Science, 146, 655 (1964).

${ }^{19}$ Gengozian, N., and Hubner, K. F., J. Immunol, 99, 184 (1967).

${ }^{20}$ Singhal, S. K., Naspitz, C. K., and Richter, M., Intern. Arch. Allergy, 31, 390 (1967).

${ }^{21}$ Borjeson, J., Rejsficld, R., Chessin, I. N., Welsh, T., and Douglas, S. D., J. Exp. Med., 124, 859 (1966).

${ }^{22}$ Ling, N. R., and Holt, P. J. L., J. Cell Sci., 2, 57 (1967).

${ }^{23}$ Jerne, N. K., Nordin, A. A., and Henry, C., in Cell Bound Antibodies, 109 (edit. by Amas, B., and Koprowski, H.) (Wistar Inst. Press, 1963).

${ }^{24}$ Dresser, D. N., and Wortis, H. H., Nature, 208, 859 (1966).

${ }^{26}$ Sterzl, J., and Riha, I., Nature, 208, 858 (1966).

${ }^{26}$ Mishell, R., and Dutton, R. W., J.Exp. Med., 126, 423 (1967).

${ }^{27}$ Meuwissen, H., Bach, F., Vanalten, P., and Good, R. A., Fed. Proc., 26, 477 (1967).

${ }^{28}$ Dukor, P., and Dietrich, F. M., Intern. Arch. Allergy, 32, 521 (1967).

${ }^{29}$ Davies, A. J. S., Festenstein, H., Leuchars, E., Wallis, V. J., and Doenhoff, M. J., Lancet, i, 183 (1968).

${ }^{30}$ Davies, A. J. S., Ieuchars, E., and Wallis, V. J., Transplantation, 5, 222 (1967).

\section{Effects of Testosterone Analogues on Interferon Formation, Induction of Antiviral Protein and Synthesis of Cell Protein in Tissue Culture}

INTFrFERoN, an antiviral protein produced by cells in response to penetration of viruses or other agents, has been extensively studied. It is known that anabolic hormones affect protein synthesis and that production and activity of interferon are sensitive to the action of inhibitors of protein synthesis ${ }^{1-3}$. Some work has been published on the influence of hormones on the production and activity of interferon, but the effects of hormones on these processes and on protein synthosis have not bcen compared ${ }^{4-6}$.
We have made comparative studies of the effect of synthetic analogues of testosterone on interferon formation, interferon activity and overall synthesis of cell protein.

Cultures of chick embryo fibroblasts (CEF) grown in Eagle's medium were prepared by a routine procedure. Interferon was produced in 5-7 day old CEF cultures, and Lee strain influenza $B$ virus in a dose of $3 E I D_{50} /$ cell was used as interferonogen. Interferon activity was determined by the plaque inhibition method in CEF culture infected with Chikungunya virus. The overall synthesis of cell protein was assayed by measuring the amount of ${ }^{14} \mathrm{C}$ glycine incorporated into acid-insoluble fraction freed from nucleic acids and lipids by extraction with 6 per cent trichloroacid and alcohol-ether mixture at $60^{\circ} \mathrm{C}$. The specific radioactivity of the isotope was $100 \mathrm{mCi} / \mathrm{g}$, and its final concentration in the medium was $0.2 \mu \mathrm{Ci} / \mathrm{ml}$. The cells were in contact with the isotope for $3 \mathrm{~h}$ and the amount of protein was determined by the method of Lowry et al. ${ }^{7}$. Testosterone synthetic analogues-dl-19-norD-homotestosterone (NDT) described by Rzheznikov et al. ${ }^{8}$ and $d$-I9-nortestosterone (N'T)-were obtained from Professor I. V. Torgov and S. N. Ananchenko (USSR AMS Institute of the Chemistry of Natural Compounds). ND'T was shown to possess a higher anabolic activity than natural hormone ${ }^{9}$. The results obtained showed that $100 \mu \mathrm{g} / \mathrm{ml}$. of NDT was the highest non-toxic dose for $\mathrm{CEF}$ and a concentration of $200 \mu \mathrm{g} / \mathrm{ml}$. produced cell degeneration. The time course of the incubation of NDT with the cells influenced the overall synthesis of coll protein (Fig. I). Simultaneous administration of NDT at a dose of $50 \mu \mathrm{g} / \mathrm{ml}$. (Fig. 1, curve I) and the isotope slightly inhibited protein synthesis, and the longer the preincubation period lasted the greater was the effect. Thus the inhibition was approximately 50 per cent after $3 \mathrm{~h}$ and 75 per cent after $72 \mathrm{~h}$. Long-term incubation of cells with small doses of ND' $(0 \cdot \mathrm{I} \mu \mathrm{g} / \mathrm{ml}$.) did not sub. stantially change the level of cell protein synthesis. The presence of the compound in the culture medium during the contact of the cells with the isotope was necessary for the realization of the inhibitory effect in addition to preincubation of cells with the compounds.

Thus in tissue culture the synthetic analogue of testosterone produced not an anabolic but an inhibitory effect on protein synthesis. Analogous data were obtained in vitro using other hormones ${ }^{10-12}$.

To study the effect of NDT on the production of interferon, the culture cells were incubated with the compound at a concentration of $50 \mu \mathrm{g} / \mathrm{ml}$. for $18-20 \mathrm{~h}$ before administration of interferonogen and for $24 \mathrm{~h}$ after it. Control infected cultures without steroids were incubated in the same conditions. NDT caused a statistically sig-

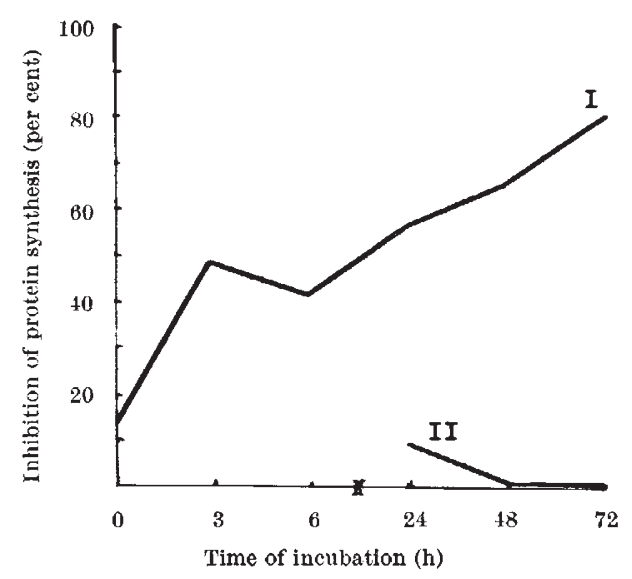

Fig. 1. Effect of time of incubation with $d l$-19-nor-D-homotestosterone on overall protein synthesis in chick embryo fibroblast culture. I, Concentration of drug was $50 \mu \mathrm{g} / \mathrm{ml}$.; II, concentration of drug was $0.1 \mu \mathrm{g} / \mathrm{m}$. 